\title{
National Representations, National Theatres: Aubrey Menen and the Experimental Theatre Company
}

Author: Florian Stadtler, Department of English and Film, University of Exeter, Exeter, UK

Correspondence Address: Department of English and Film, University of Exeter, Queen's Building, The Queen's Drive, Exeter, EX4 4QH, UK, E-mail: f.c.j.stadtler@exeter.ac.uk

\begin{abstract}
:
This article discusses the Indian-Irish playwright and critic Aubrey Menen's involvement with London's theatre scene in the 1930s. Aubrey Menen became heavily involved in student drama activities while a philosophy student at University College London. He co-founded the London Student Players as well as the Experimental Theatre company, a group on London's theatre fringe which sought to produce plays that were of the moment, politically current, pushing the boundaries of theatrical staging in alternative performance spaces. At the age of 21, Menen also became the dramatic critic for the monthly magazine, The Bookman. Menen used his column to offer a sharp critical dissection of the state of British theatre and to lay out a plan for a theatre that can call itself truly 'national' and how this might be achieved financially, artistically and practically. This essay highlights the wider context of Menen's own pronouncements in The Bookman, exploring these as part of his engagement with London's alternative theatre scene in the 1930s. It argues that Menen's ideas were a timely intervention into crucial debates how the nation should be represented in drama and how drama could reach an audience beyond the middle classes, preoccupations that are still hotly debated today.
\end{abstract}

Keywords: Aubrey Menen, British Asian Theatre, National Theatre, Experimental Theatre Company, Alternative Theatre Scene

Acknowledgments: This work was supported by the British Academy under Grant SG-54032. I would also like to acknowledge the generous feedback, mentorship and advice of Professor Susheila Nasta, Principal investigator of the AHRC funded cross-institutional project, Making Britain: South Asian Visions of Home and Abroad, 1870-1950. Thanks are also due to the curators and archivists at the Howard Gotlieb Archival Research Center, University of Boston for their assistance with the archive of Aubrey Menen. 


\section{National Representations, National Theatres: Aubrey Menen and the Experimental Theatre Company}

Debates around questions of representation in relation to the programming of a National Theatre have been long-standing and wide-ranging in the UK. They centre on the way in which the nation articulates itself through drama on a national stage and the extent to which plays should be a reflection of the state of the nation. This issue remains current with inaugurations of a National Theatre of Wales and Scotland, and on-going considerations at the National Theatre in London to diversify its programming.

Here, debates from the 1930s allow us to engage productively with some of these issues, which were taken up in a series of columns in the magazine The Bookman by the Indian-Irish writer and playwright, Aubrey Menen, in which he offers thought-provoking analyses of the theatre of the mid-1930s. He frequented Left Theatre circles and together with the actor André van Gyseghem he participated in a wider debate around the state of theatre. Especially the question of how it could innovate and reinvent itself afresh to become more representative of Britain was at the fore of their concerns. Issues of representation play a large role here, especially Menen's own awareness of his mixed racial identity and dual heritage, as well as his experience of racial discrimination.

He was born in April 1912 to an Indian father, who arrived in London in 1908 as a medical student, and an Irish mother. He grew up in Honor Oak Park, South East London. From early on in his life, he was keenly aware of his own difference. He confronts a constant struggle between the character traits of his ancestries and the process of receiving an English education which proved formative for his outlook on life and led to deep conflicts about his own place within Britain, leading to a playfully articulated yet profound self-questioning self-analysis. For him, this positioning was no trivial matter, especially in the context of the twilight years of the British Empire, which he describes with much sardonic irony: 
As an Englishman I was able to treat both the Irish and the Indians as my inferiors so long as I was careful to speak of them to their faces as my equals. This formula was the basis of an astonishing organisation called the British Empire and remained so until the formula was finally understood by the subject races.

(Menen 1954, 8-9)

His autobiographical writing explores the difficulties of his own identity negotiations. At his feepaying school, his teachers ensured that he would not be discriminated against. Yet he sharply reflected on issues around his identities, which remained important source material for him throughout his life.

As a student he lived in Charlotte Street, off Tottenham Court Road. He studied philosophy at University College London and became heavily involved in student drama activities, including a successful stage adaptation of H G Wells's novel, The Shape of Things to Come, which gained much publicity. Soon after, at the age of twenty-one, he took up a new position as dramatic critic for the Bookman and he was one of the producers of the Experimental Theatre, which he managed with André van Gyseghem and for which he wrote and produced a number of plays from 19341937. The Experimental Theatre ceased activity in 1937 due to a lack of funds. Menen worked in theatre at a time when relatively few actors from black and Asian backgrounds were performing on the London stage. The casting of such actors remained controversial. For instance, When Paul Robeson played Othello at the Savoy theatre in 1930, alongside Peggy Ashcroft as Desdemona, the reviews were decidedly mixed and he received letters, which were covertly and overtly racist (see Cochrane 107). After the folding of two other notable theatre companies, the Indian Art and Dramatic Society and the Indian Players, little South Asian drama involvement can be traced on the London scene, and Aubrey Menen, along with Samuel Fyzee Rahmin were two of the few Indians who had their plays performed in the 1930s (Chambers 2011, 84). 
Thus far, attention on Menen's work has almost exclusively focused on his literary work, especially the novel, The Prevalence of Witches (1947). However, his early career as a theatre practitioner in the 1930s reveals another dimension to his consideration of mixed racial and national identities. He raises questions how theatre engages with the notion of nationhood and its link to identity formations. Particularly of interest to him are the ways in which such narratives are staged and dramatized, how these issues link up with emergent ideas for a national theatre, and the role and space for drama to articulate and narrate the nation.

Andrew Davies has highlighted well the range of issues faced by theatre producers, actors and directors in the 1930s in his study, Other Theatres: The Development of Alternative and Experimental Theatre in Britain (1987). He notes that at the time, naturalistic representations of middle class life were prominent features of drama, especially in the commercial West End (1987, 80). The trends in experimentation with theatrical form, which could be seen elsewhere at the time in Germany or Russia, for example - were hampered by rigours censorship by the Lord Chamberlain. Yet the First World War and its aftermath necessitated a different form of debate about the 'state of the nation'. Here, a wider question of a national theatre emerges. One such alternative space was the Old Vic and Sadler's Wells, which, as Davies argues, were places that under the directorship of Lilian Baylis 'offered a comprehensive repertoire which included plays, ballet and opera and stood in contrast to the West End' $(1987,84)$. However, the financial pressures under which it operated meant that by the 1930s it functioned, 'less as an alternative than as a supplement to the commercial stage' (Davies 1987, 84). The development of alternative and more experimental theatre took place in the regions and in smaller performance spaces outside the commercial West End. It was pioneered by groups such as the British Drama League, Sean O'Casey at the Abbey theatre, repertoire theatres in Birmingham and Liverpool, the People's Theatre of Newcastle, The Maddermarket, Terence Gray at the Festival Theatre, the Gate, the Lyric and the Group Theatre. For Davies, 'these organisations gave an indication of just what achievements and successes experimental theatre could create' $(1987,93)$. Through these groups, 
different methods of acting, for example the use of improvisation, were championed and experimented with, countering the formalism so prevalent in the West End. However, while these groups and performance spaces were important for a development of a new style of performance, they often found themselves in precarious financial situations, because of their inability to find a sustainable audience base. This can be attributed to the rise in popularity of other forms of entertainment in the 1930s, especially of cinema and radio. As Davies highlights, 'by 1931 [...] one family in three owned a radio set, a figure which by the end of the decade had risen to three out of every four families' (94). By the late 1930s, the country's theatres were competing with some 5000 cinemas. The worsening financial situation led to many theatres closing down and some being converted into cinemas.

The 1920s and 1930s saw a rise in political groups, and many of these explored the role for theatre in educating the masses. As a consequence, these organisations sought to 'solve the question of widening the social basis and habits of theatre-going' (Davies 1987, 95). Whilst the mainstream Labour movement showed little interest in the arts, the Co-operative movement sponsored numerous local drama societies, with 49 running by 1937 (Davies 1987, 98). The actor and producer, André van Gyseghem, who would later work with Menen to establish the Experimental Theatre Company, attempted, unsuccessfully, to persuade the London Co-operative to establish a permanent cooperative workers' theatre (Davies 1987, 99).

Experimental theatre was largely staged by groups who were politically left of the Labour Party - especially the Independent Labour Party and Communist Party of Great Britain took an interest in how its political message could be conveyed through drama. The development of new audiences formed an important part of these considerations as well as experimentation with alternative performance spaces to reach a demographic beyond the middle classes. The Workers' Theatre Movement, Rebel Players, Unity Theatre and Left Book Club Theatre Guild pioneered this work. In 1922, the Independent Labour Party established the Arts Guild, with the specific brief to present modern plays and films of social importance and to involve well-known actors and actresses 
to ensure quality as well as audience attendance and to sell seats at prices affordable for workingclass families. One of the most active supporters of this work was the Communist Party of Great Britain. Clemens and Rajani Palme Dutt, who both edited Labour Monthly, published much on the topic. By the mid-1920s, the Workers' Theatre Movement was well established, but by the early 1930s, the movement was floundering, due to a lack of suitable plays as well as criticism for its amateurish productions. Yet the impact of rising unemployment caused by the 1929 Wall Street Crash and the rise of Fascism meant other theatre groups saw the urgent need to directly respond to these pressing issues, which the West End commercial sector largely overlooked.

Aubrey Menen was particularly active in UCL's Student Players, for which he wrote, directed and performed. Menen made important connections living in the Bloomsbury area of London, commissioning Duncan Grant to design sets, as well as persuading H G Wells to allow him to adapt The Shape of Things to Come. By the mid-1930s, drama societies were seen as an important extra-curricular activity. For example, the 1920s saw the growing importance of the Cambridge University's Amateur Dramatic Club and the Oxford University Dramatic Society. As Claire Cochrane points out, 'the practice of employing professional directors and invitations to selected professional actresses to play female roles, allied with the elite status of the students, meant that ADC's and OUDS's productions could attract distinguished audiences which included theatre critics from national newspapers' $(2014,91)$ The Student Players emulated a similar strategy, but Menen proposed more radical content, productions and non-traditional performance spaces.

Van Gyseghem and Menen's experimentations are closely aligned with the innovation pursued in Little Theatre circles and influenced by German expressionism on socialist theatre in Britain. As Raphael Samuel and his co-authors point out, 'instead of the deference to high culture, there was an iconoclastic desire to break with it, no less apparent in, say, the Plebs League - the trade union based and mainly Labour Party federation of working-class autodidacts - than among Communists. Instead of moral up-lift, there was agit-prop, a self consciously revolutionary art' (1935, xix). This inspired him especially in terms of his programming at the Experimental Theatre 
Company. Whilst at UCL, the Student Players' work used montage and mass spectacle, so prevalent in the work of German post-World War I expressionist theatre. Menen's work eschewed a form of naturalistic representation and bourgeois moral values. Van Gyseghem brought to the partnership his own experience with spectacle through his work at the Embassy Theatre, where he had staged Hans Chulmberg's epic play, Miracle at Verdun in 1932. His work with Menen marked a short interlude, before he would move on to the Unity theatre.

If we compare and contrast Menen's conceptual writings with his work as practitioner, we can see that he commits himself to the developments that have been taking place in Little Theatre, Left Theatre and amateur circles and elaborates how they might be the basis for a renewed discussion about a national theatre. His propositions are indeed radical. In October 1933, Menen became the new drama critic for the monthly magazine, The Bookman. He penned his column over the next eight months, from October 1933 to May 1934, vigorously debating the state of the theatre in London. His contributions went beyond the mere reviewing of plays, but came out of his own experiences on the student amateur circuit at UCL. Perhaps more significantly, these pieces of journalism reveal a successive deconstruction of the state of theatre in London and Britain by offering a sharp dissection of its component parts. His October column opens with a survey of plays presented in London; in November he moves on to a discussion of acting styles of male performers. For December, he looks at the Ballet; in January he compares the state of British theatre in relation to Britain's wider cultural output and unfavourably contrasts it with Germany and France, following up this argument in the subsequent month with his 'Plan for a Theatre'. In this column, he offers sharp criticisms of London's theatre scene and outlines a new plan for a national theatre. He returns to this issue in his penultimate piece for the Bookman in April 1934, having received feedback from readers and other theatre practitioners, most notably Lilian Baylis who managed the Old Vic and Sadler's Wells theatres at the time. He intervenes here in ongoing debates around a National Theatre, which had gained renewed momentum from the 1920s onwards after the inception of the British Drama League. His own pronouncements in The Bookman, are thus linked to his 
engagement with London's alternative theatre scene in the 1930s and the important debates around the role and place of theatre in Britain's cultural life.

André van Gyseghem, then involved with the Rebel Players and the Embassy Theatre in London, ran the Embassy as a club with subscription fee, which allowed him to circumvent the Lord Chamberlain's censorship. In an autobiographical essay, 'British Theatre in the Thirties', he provocatively claims that in the early 1930s the British stage was dominated by plays catering for middle-class audiences (van Gyseghem 1979, 209). For him, the theatre had a limited audience reach and lack of representation. This led him to explore other opportunities. The early 1930s saw a small rise in alternative theatre and performance spaces in London. He sought out the Workers' Theatre Movement, based in the East End of London, and went on to work for the Rebel Players and started to make his name in theatre circles of the political Left (Van Gyseghem 1979, 210). He joined the repertory company of the Embassy Theatre in Swiss Cottage, London in 1930 where he acted, directed and produced plays, and in this period, he forged a working relationship with Menen. Together they founded the Experimental Theatre Company in 1934 (Van Gyseghem 1979, 211). The new venture was launched with an announcement in The Times on 2 November 1934 and followed six months after Menen had penned his last column in The Bookman. Based at 59 Finchley Road, the venue had capacity for 120 people. This theatre offered a new style of performance, with many shows based on current affairs, immediately responding to the political concerns of the day.

The 1930s theatre scene in London was marked by upheaval and change. Similar to other forms of artistic expression, the theatre had to adapt to find a way of engaging with the dramatic political, economic and social changes of the previous decade. How could drama respond to the aftermath of the First World War, the 1926 General Strike, the First Labour Government, on-going class inequalities, the reform of divorce laws, and the advent of full female suffrage? How would this impact on perceptions of Britain as a Nation? How could theatre be developed into a political and propaganda tool for a British context? What power does theatre have as a medium of artistic expression? 
Theatre was also threatened by new technological innovations that challenged its financial viability. Especially cinema was seen as a major threat to the theatre, and Menen comments on this repeatedly in his columns for the Bookman. Through the consolidation in the commercial West End, room for new aesthetic experimentation was curtailed, and as a consequence, London saw the growth of a variety of different types of 'theatre' for its different audience constituencies. The commercial sector was dominated by business-minded financiers and managers keen to pander to its core audience's tastes; and with a lack of state funding in the period there was a marked imbalance in theatre devoted to the development of drama and dramatic text and theatre that operated as a commercial enterprise. As Maggie B. Gale in the 'The London Stage, 1918-1945' notes, theatre in the 1920 s and 1930 s became 'an economic investment for capitalists who were more interested in the financial viability of a production than in its social significance or aesthetics' (2004, 147). Experimentations with aesthetics, dramatic text and new ways of presentation were largely confined to what at the time was called 'Other Theatre' a phrase first introduced by theatre producer and historian Norman Marshall.

'Other Theatre' comprised subscription clubs that produced Sunday night or Monday afternoon performances, and small independent theatres. These were operated on a not-for-profit basis to absorb some of the risks in producing plays by new and unknown writers. A number of these societies flourished in the 1920s: these included the Stage Society, Pioneer Players, Three Hundred Club and the Venturers. As Gale notes, these 'provided a platform for experiment and partial alternative to the West End monopoly' (2004, 150). The work of the Experimental Theatre Company needs to be considered in this context. These societies also offered opportunities for amateurs and professionals to work together. Gale further explains:

In addition many of the playwrights and professional performers worked in both the commercial and the other theatres, sometimes alleviating the tedium of West End engagements by Sunday 
performance projects. [...] Others were set up by playgoers whose taste significantly differed from that of the Lord Chamberlain's Office and West End theatre management. $(2004,150)$

By the end of the 1930s most of these societies had ceased due to financial difficulties and the nature of professional actors' touring and performance schedules (see Gale 2004, 150). The London theatre scene comprised a number of small independent theatres such as the Everyman, the Embassy, the Arts and the Gate theatres committed to producing new and experimental plays. Funded by subscription, with patrons paying a membership fee for a club, had the consequence of low or non-existent wages for actors and crew, and minimal facilities. Productions had short runs and actors often left for better paid jobs in larger theatres.

This type of experimental theatre received a harsh reception from critics. Menen's work was no exception as is evident in some of the reviews of his plays in The Times and the Manchester Guardian. For many critics, these shows were deemed not populist enough and far too 'high-brow' for the majority of theatregoers. For instance the Times reviewer of Menen's 1935 adaptation of James Jeans's The Mysterious Universe, which debated astronomy and physical science and its impact on humanity's outlook on the universe in relation to human life, writes that the characters 'mouthed gigantic nothings with an occasional titter of facetiousness'; he continuous 'what $\mathrm{Mr}$ Aubrey Menon ${ }^{1}$ wishes, or seems to wish, to express is an adverse opinion of the Creator; [...] More than this it is impossible to distinguish, for if Mr. Menon has ideas, he is too clever or too discreet to express them.' The 1936 Times review of Requiem for an Idiot is equally dismissive: 'In Requiem for an Idiot there is no inspiration, but a mere drolling of platitudes.' Yet as Philip Godfrey noted, smaller stages and companies such as the Experimental Theatre were a crucial attempt 'to prevent dramatic art from being wiped out by the commercially minded' $(1933,160)$. Writing at the time, Godfrey's assessment of experimental art theatre is damning; he accuses practitioners of inconsistency, arguing that it moved towards 'small and ineffectual art coteries' who revelled in the maintenance of censorship which increased publicity, rather than 
wholeheartedly campaigning for its abolition $(1933,170)$. Yet Menen would consider the practice of art theatre as a way forward in making theatre relevant to contemporary audiences.

In his last year at UCL, Menen had founded a breakaway company of players. The official Dramatic Society was preoccupied with a financially lucrative presentation of five plays written by Laurence Housman, the brother of the poet A. E. Housman, with a new one each year, entitled The Little Play of St Francis. The company had signed a contract with a charity that ran a Boy Settlement in the East End of London and depended upon the play for money. However Menen and a number of fellow actors rebelled at the lack of opportunities to put on different plays, and he founded the London Student Players. This new group drew from a constituency beyond UCL including the Royal Academy of Dramatic Arts and the London School of Economics. Menen's group was influenced by the theatre of Nikolai Okhlopkov, known for his large-scale outdoor productions, which Menen replicated to great effect in his staging of Siegfried and the Passion Play, which were both praised in the press for their innovative staging and unusual use of space.

The adaptation of H.G. Wells's The Shape of Things to Come was the group's flagship production for 1933. The story of its production is well documented in his unpublished biography, Graham and the Elephants (Aubrey Menen Collection, Howard Gotlieb Archival Research Center at Boston University). For the young Menen and his generation, H G Wells was not only the writer whom they had read as teenagers, but who by the 1930s was regarded as prophetic. Wells's pronouncement on the future struck a particular chord with the young Menen. He was so enthralled by the book that he wrote a dramatisation, which he sent Wells with the request to produce it with the London Student Players in the theatre of the London School of Economics. Yet the show nearly did not get off the ground. Wells had already sold the rights to the film producer Alexander Korda, who would release his movie version in 1936. To overcome the impasse, Wells persuaded Korda to allow three un-reviewed closed performance of the play. Yet information about the production was leaked and the play generated much publicity when it opened in November 1933. On the evening of the first night the drama critics of The Times, the Daily Telegraph, the Manchester Guardian, the 
Observer among others did turn up. Before the performance, Wells would prepare the critics, talking excitedly about the play (Graham and the Elephants). At Wells's invitation, the critics did attend the performance, and in the next day's write-up in the papers other than announce that the play had been performed and who was involved they could not offer anything substantial by way of a review.

In his personal papers, Menen explains that he was influenced by the expressionist drama of the 1920s in Germany and the young Soviet Union. In his staging of The Shape of Things to Come, critics and avant-gardists might see 'constructivist' traces, in its use of a set consisting of Stepladders and wallpaper and lighting effects. Yet his constructivist set for the play was not only an aesthetic marker but dictated by a lack of funding, requiring ingenuity on his part. Actors positioned these props as necessary on the stage to evoke the play's settings - a bombed house, the Stock Exchange or Danzig. The following two performances were a sell-out. Menen made his name on the back of these three performances and his association with Wells.

The avant-garde of the London theatre world had come to see what they would perceive as 'constructivist' scenery in action. Even the recently arrived Ernst Toller, the playwright of The Mass Men and at the forefront of German expressionist theatre, was in the audience. The play's future success was scuppered by the Lord Chamberlain, who banned all further productions of the play because of the portrait of Hitler and the play's suggestion that he would start another war over Danzig. For Menen, however this did not matter as the sensational staging of the play had brought him into contact with the theatrical innovators working on London's theatre fringe, including van Gyseghem. Menen acted in two of his productions, and van Gyseghem, acted in Menen's 1934 play

\section{Genesis II.}

Genesis II was a response to an incident when Menen was a student at UCL. He had won the 'Rosa Morison' bursary for an essay. But instead of the prize money he was given a parchment and some presentation volumes, as, so the Dean informed him, the bursary was reserved for people of 'pure British descent on both sides.' He explains: 
The Dean was academically indignant: to soften the blow he added that I at least had the advantage of being a member of two cultures and that could prove to be a great thing. Since his name was Solomon and he was a Jew, he should have known better, and probably did.

(Menen 1970, 39)

The play begins with the creation, a dialogue between God and a fertilised egg cell, continues with the story of Adam and Eve and then moves on to Moses, Nebuchadnezzar, John Ball, and Karl Marx. The setting shifts from the Garden of Eden to Egypt, Babylon, Kent, A Chinese Rice Plantation, the British Museum Reading Room, a police station in Germany in 1934 and ends near Battersea Power Station. It was a re-telling of the first chapters of the Bible but slowly diversified and focussed on the suppression of one race by another. This would prove to be his most controversial play. It was staged in June 1934 at the Fortune Theatre and featured Make-Up and Masks by Bloomsbury artist, Duncan Grant, who lived close to him in Charlotte Street, scenic design by John Rowden, and starred André van Gyseghem and Barbara Nixon, a founding member of the Left Theatre.

The play caused a minor scandal and the Lord Chamberlain prosecuted Menen, fining him $£ 5.00$. The Lord Chamberlain also fined the proprietors of the Fortune Theatre for a breach of their licence because the theatre had no permission for Sunday performances. The company through a form of subscription tried to avoid the censor. In the event, members of the audience had alerted the Lord Chamberlain's office to the play. The fertilised and unfertilised egg cells, played by Diana Gould and Barbara Nixon, caused particular offence. Menen's lawyer was glad that only the allegedly obscene and blasphemous elements of the play were mentioned in court and not its arguments on race and anti-imperialism as the lawyer was 'quite anxious that the true subject of the play should not be brought up in court. He knew the magistrate; he was no churchgoer, but he was a staunch upholder of the British Empire' (Menen 1970, 70). No script of the play was published or can be traced in his archive. His autobiography, the programme and the reviews of the play reveal 
though that it is informed by his studies in philosophy; he explores the relationship between the individual, religion and God, who in the play first appears as the Creator and then is reincarnated in various guises and ends up in the figure of Karl Marx. The play asks questions about tyranny and revolutionary action and draws comparisons between the Bible and Das Kapital. The Times reviewer sees the play's arguments not leading anywhere in particular and criticises the play for being overloaded with ideas that are never fully developed. Yet he praises him for his gift of irony and witty epigrams. The mini-scandal generated more publicity for him and the newly founded Experimental Theatre.

Through van Gyseghem, he came into close contact with the avant-garde of German theatre, such as Ernst Toller, Kurt Weill and Bertolt Brecht, who frequented van Gyseghem's flat. He sought to re-work the style of their theatre for a British audience and looked out for alternative performance spaces and innovative ways of staging. Avant-guardism was not his main agenda though - lack of funds seems to have been the major driving force behind his innovations. Yet at the same time he pushed the boundaries of theatrical staging, performance and the subject for drama, for instance through the company's aforementioned adaptation of James Jeans's The Mysterious Universe at the Arts Theatre Club in July 1935, and in 1936 a newly devised play Requiem for an Idiot. The play was announced in The Times on 24 October 1936, only three weeks after the Battle of Cable Street. In the play, the set consisted only of a coffin in the middle of the stage. Conceived as a social satire, it is the story of a Jew shot in a street riot. Four characters, a financer, a politician, a duchess and a soldier all claim him as a hero at his wake. However their thinly disguised prejudices come through at the end. These plays were complemented by oneminute performance pieces improvised from newspaper headlines that the audience had brought in, replicating the newsreels in the cinema.

Menen's work as a theatre practitioner aligns with his writing on theatre and shapes his ideas around a type of theatre that can be perceived as 'national'. In his column 'Brief Chronicles: Theatre' in The Bookman, he articulates his fears about the survival of theatre as an art form. In his 
December column, 'The Ballet Provokes Reflection', he argues that 'it will most certainly be superseded by the cinema and its close-ups of passion and social putrefaction if the theatre does not exercise its right to be intelligent' (Menon 1933, 173). He goes on to argue,

The theatre which will survive the film stars is one which will care no more about patterning than the mathematician cares about the abacus; it will house plays which are demonstrations of things which will have been demonstrated in pamphlets and books and textbooks; but because it can conjure up reality by its symbols, and underline and emphasise by means of its actors and producers, the theatre will demonstrate these things more forcibly.

(Menon 1933, 173)

He first writes about the idea of a National Theatre in his January column 'The Theatre - Living or Dead'. He suggests that any place licensed for entertainment should be subject to playing a specific quota of British plays - this would lead to a wider audience viewing theatre and would lead to a revolution in tastes. The public would realise "that they had on their library shelves the finest plays of any time or country in the world' (Menon 1934a, 395). In this column he suggests closing down the Old Vic and asking Lilian Baylis to run a National Theatre. He argues for the need to produce theatre that could truly be called 'national', which would produce plays of 'biting social comment, political and propagandist plays of the moment; plays which are as vivid as the morning paper, often quite as irritating, but always as vital' (395). This would be a break with tradition, but he argues that this innovation would turn theatre into 'something belonging to the present time and to present-day audiences' (395). For him, it is important to highlight what contemporary theatre is producing and the manner in which it challenges the politics of the day. These considerations lead him to propose a new plan for a national theatre in his February column.

His interventions need to be viewed in the context of the larger campaign for a national theatre, led since the early twentieth century by Harley Granville Barker, who published A National 
Theatre: Scheme and Estimates in 1907 and A National Theatre in 1930, which further concretised his proposals in the post-World War I context. For Granville Barker, the goal of a National Theatre was to deliver a 'representative repertory of good English plays throughout the Empire' and to 'stand as a symbol of a cultural unity and a beneficent bond' (1930, 115). The debate around a National Theatre was advanced further by the inception of the British Drama League in 1919, with which Granville Barker was involved. The League kept this debate alive through conferences and publications, for example in the journal, Drama. As Cochrane points out, 'the organisation was simultaneously about creating a stronger, more innovative professional theatre and nurturing an energetically participating British population, who would also form a suitable educated audience base' $(2014,111-12)$. The League did much to galvanise and consolidate drama as a participatory act of artistic expression. Though directed from London, it sought to bring together amateur and professional, regional as well as national organisations under its umbrella. Granville Barker's revived scheme had a wide range of supporters, most notably George Bernard Shaw. However, while Granville Barker's proposals were pioneering insofar, as they called for a theatre with two stages and a resident repertory company with a rotating list of plays, he would not consider opening one of these stages for experimental theatre innovators. As Geoffrey Whitworth, who was involved in the campaigns in the 1930 s recalls,

Half-baked or tentative productions would have been relegated to their proper place, the Little or Studio theatres where the public could enter at their peril and under no misunderstanding that they were being invited to assist at anything more than an experimental production, amusing perhaps in itself but quite unsuited to a national theatre.

(Whitworth 1951, 191)

Menen criticises this conservative attitude towards the role, function and programming of a 'national' theatre. He thinks that precisely this type of experimentation should be the cornerstone of 
a 'national' theatre; it should strive to be a theatre that speaks to people's concerns in the present and have a connection to their experiences in their every-day lives.

He was of the opinion that to get a National Theatre off the ground in financial terms would be no obstacle, but a larger problem would actually be in defining its role: 'There would be no difficulty at all in getting a National Theatre if only we knew precisely what we were asking for' (Menon 1934b, 437). In his scheme for a national theatre, playwrights

will be expected to write plays, which will at least pay their way, precisely as an actor is expected to know enough about his job to avoid being booed off the stage every time he makes an entrance. A play which appeals to five hundred pounds worth of theatregoers must cost fivehundred pounds and not a penny more. (437)

The obvious source of financing a national theatre would be to apply for funding from the Government. However, he thinks that the nation would not value an institution like a national theatre, if it did not contribute financially to it. Further, in his plan, his national theatre would recruit an audience on a nation-wide basis - all 'theatrically minded' people of the whole population of Britain. He admits that it is questionable that such an audience exists. A committee for a national theatre should be drawn from this audience constituency to form district associations for the National Theatre, and they would determine which play would be staged in their regions. In his scheme the play and actors would tour the regions in several companies performing productions that could take up residency in a variety of venues, ranging from town halls to a circus tent. His idea for financing would be from subscriptions from audience members and donations - in the long run the Government would have to subsidise it should it run at a deficit; but 'in the meantime we have this plan for getting our audience, our theatre, and earning an honest penny to pay the cost' (Menon, 1934b, 437). 
He broaches what makes theatre 'national' and what role it fulfils. How does it contribute to national identity formations and how are these affiliations produced in and through theatre? Implicit here are wider questions about nation, identity and representation. In the context of the new millennium, Jen Harvie argues that through theatre national identities can be 'creatively produced or staged' $(2005,2)$. She suggests that 'if national identities are creatively imagined, that means they are dynamic' $(2005,3)$. For Menen this dynamism needs to be central to a national theatre, rather than it being a museum for revivals of old plays that are no longer relevant in a contemporary context. One might argue that his own complex identity - Indian Irish and British - allows him to recognise this potential dynamism more clearly. The main question, then, is about audience and widening it, how to make theatre attractive to people from different class backgrounds, in other words to those whose lives and experiences are not represented.

His proposal provoked mostly positive reactions from theatre practitioners and critics, and he responded to these in the April issue of the Bookman. Most notable was the letter from Lilian Baylis to the editor of the Bookman, dated 8 February 1934. She considers her work at Sadler's Wells and the Old Vic as very much running a people's theatre. She concurs with him that a fully subsidised theatre by the Government would lead to the public not valuing it as an institution. However any institutions survival is premised on its financial viability. Hence support not only through ticket sales but donations towards the upkeep of the building proved essential. This in turn would lead to larger donations from financial backers. However, she is sceptical of his suggestion to conceive a National Theatre along the lines of several touring companies with London at their centre. The mode of financing in the regions by subscription comes in especially for criticism. In her opinion, given the spread of the cinema to the regions, with every village having its own cinema, she does not think that a theatrical touring company with higher ticket prices would attract enough attention to be financially viable. She asserts that the cinema has only received competition in the provinces from the repertory theatres, some of which have been subsidised by local authorities. She attribute their success to the connection audiences have established with the companies' actors and the thrill 
to see them taking on different characters. She also raises the question who would decide which plays are to be performed - is this a centralised decision made in London or are local voices to be considered? Indeed, such a question is of primary importance if one is to build a theatre that can encompass, represent, and cater for the tastes and concerns of the nation in all its diversity. She points out that he remains vague on what subject and which playwrights he deems to be central to an idea of a national theatre.

Nancy Price, director of the People's National Theatre ${ }^{2}$ and a long-standing supporter of a subsidised repertory company, also praises his intervention and adds that 'you must remember that the theatre is not merely a place for the entertainment of love-starved old ladies. It is also among other things a powerful weapon of propaganda' (Menon 1934c, 34). Both Baylis and Price raise questions about the type of play a national theatre should perform. Menen rejects Baylis's suggestion that Shakespeare should be the national dramatist and at the heart of the playbill of a National Theatre. He also dismisses Price's suggestion that it should be anyone from Ibsen to Clifford Bax. Instead, he favours contemporary dramatists such as Ben Travers, Edgar Wallace and Noel Coward. However, he argues, if the national theatre has any aspirations to be national and democratic, then local associations should determine which playwright and which type of play should be performed.

In his early engagement with theatre, Menen was clearly influenced by the changing nature of drama, no longer just an expression of bourgeois sentiment and a source of entertainment for the upper middle classes. His plan is his way to 'nationalise' theatre. The theatre he advocates is a type of political theatre that seeks to disrupt, subvert and question discourses around the conceptualisation and representation of a nation. In his own work with the London Student Players and the Experimental Theatre he sought to create a theatre that was relevant to present day circumstances of its audience to offer critical evaluations of the state of the nation. For him, a truly national theatre cannot be confined in one building in London, but needs to go out and 
communicate with a wider audience drawn from all sections of society both metropolitan and urban, as well as provincial, rural and based in the regions.

The Experimental Theatre, the type of plays it produced and their choice of venue and innovative staging can be viewed as a way of exploring ideas for a different, more dynamic and immediately involving type of theatre that he envisaged in his Bookman columns. His contemplations on a National Theatre are a timely intervention into crucial debates about how the nation should be represented in drama, ways in which it might compete with newer forms of artistic expression, such as the cinema, and how it could reach a wider audience, that was not exclusively white, urban and middle class. In this respect his ideas about the representations of a wider nation and the significance of drama in this process, still resonate today. His dramatic work exemplifies an understanding that what constitutes an idea of the nation needs to be a continuing subject for debate. In this sense, theatre fulfils an important function in engaging, staging and producing identities, however unfixed and unstable these may be.

Acknowledgments: This work was supported by the British Academy under Grant SG-54032. I would also like to acknowledge the generous feedback, mentorship and advice of Professor Susheila Nasta, Principal investigator of the AHRC funded cross-institutional project, Making Britain: South Asian Visions of Home and Abroad, 1870-1950. Thanks are also due to the curators and archivists at the Howard Gotlieb Archival Research Center, University of Boston for their assistance with the archive of Aubrey Menen.

\section{Works Cited:}

Chambers, Colin. 2011. Black and Asian Theatre in Britain: A History. Abingdon: Routledge.

Cochrane, Claire. 2011. Twentieth Century British Theatre: Industry, Art and Empire. Cambridge: Cambridge University Press. 
Davies, Andrew. 1987. Other Theatres: The Development of Alternative and Experimental Theatre in Britain. Basingstoke: Macmillan.

Gale, Maggie B. 2004. 'The London Stage, 1918-1945.' In Vol. III of The Cambridge History of British Theatre, edited by Baz Kershaw, 143-166. Cambridge: Cambridge University Press.

Godfrey, Philip. 1933. Back-Stage: A Survey of the Contemporary English Theatre from Behind the Scenes. London: Harrap.

Granville-Barker, Harley. 1930. A National Theatre. London: Sidgwick \&Jackson.

Menen, Aubrey. MSS Requiem for an Idiot. Aubrey Menen Archive. Howard Gotlieb Archival Resource Centre, University of Boston, Massachusetts, USA.

-. MSS Graham and the Elephants. Aubrey Menen Archive. Howard Gotlieb Archival Resource Centre, University of Boston, Massachusetts, USA.

Menen, Aubrey. 1954. Dead Man in the Silver Market. London: Chatto \& Windus.

—. 1970. The Space Within the Heart. London: Hamish Hamilton.

Menon, Aubrey. 1933. 'The Ballet Provokes Reflection.' The Bookman 85 (507): 173-4.

—. 1934a. 'The Theatre - Living or Dead.' The Bookman 85 (508): 395.

—. 1934b. 'Plan for a Theatre.' The Bookman 85 (509): 437.

—. 1934c. 'Some Opinions on the Plan For a Theatre.' The Bookman 86 (511): 34.

Samuel, Raphael, Ewan MacColl, Stuart Cosgrove. 1935. Theatres of the Left 1880-1935: Workers' Theatre Movements in Britain and America. London: Routledge \& Kegan Paul.

Van Gyseghem. André. 1979. 'British Theatre in the Thirties: An Autobiographical Record.' In Culture and Crisis in Britain in the Thirties, edited by Jon Clarke, Margot Heinemann, David Margolies and Carole Snee, 209-218. London: Lawrence and Wishart.

Whitworth, Geoffrey Arundal. 1951. The Making of a National Theatre. London: Faber and Faber. 
${ }^{1}$ Aubrey Menen changed his name from Menon to Menen in the late 1930s so as not to be confused with V K Krishna Menon, Secretary of the India League, who campaigned for Indian independence. This article uses his adapted name.

${ }^{2}$ Under her leadership the company presented a worthy repertory of history plays by writers such as Clifford Bax and John Drinkwater, poetic dramas including those of W. B. Yeats, and 'realist' plays in the style of Ibsen and Shaw. 